ORIGINAL ARTICLE, MEDICINE

\title{
Immunophenotypic Modulation of the Blast Cells in Childhood Acute Lymphoblastic Leukemia Minimal Residual Disease Detection
}

\author{
Hasan A. Burnusuzov' ${ }^{1}$ Mariya I. Spasova ${ }^{1}$, Mariana A. Murdjeva ${ }^{2}$, Angelina A. Stoyanova ${ }^{1}$, \\ Ivan N. Mumdziev' ${ }^{1}$, Valeriya I. Kaleva ${ }^{3}$, Milena I. Belcheva ${ }^{3}$, Miroslava N. Bosheva ${ }^{1}$ \\ ${ }^{1}$ Department of Pediatrics and Medical Genetics, Medical University of Plovdiv, Plovdiv, Bulgaria \\ ${ }^{2}$ Department of Microbiology and Immunology, Medical University of Plovdiv, Plovdiv, Bulgaria \\ ${ }^{3}$ Department of Pediatrics and Medical Genetics, Medical University of Varna, Varna, Bulgaria
}

\section{Correspondence: Hasan Burnusu- zov, Department of Pediatrics and Medical Genetics, Faculty of Medi- cine, Medical University of Plovdiv, Plovdiv, 15A Vasil Aprilov Blvd, 4002 Plovdiv, Bulgaria E-mail: hassan_md@abv.bg Tel.: +359892979279}

Received: 17 Feb 2016 Accepted: 11 April 2016 Published: 30 April 2016

Key words: MRD, flow cytometry, immunophenotypic modulation, childhood ALL

Citation: Burnusuzov HA, Spasova MI, Murdjeva MA, Stoyanova AA. Immunophenotypic modulation of the blast cells in childhood acute lymphoblastic leukemia minimal residual disease detection.

Folia Medica 2016;58(1);28-35, doi: 10.1515/folmed-2016-0004
Early clearance of leukemic cells during induction therapy of childhood acute lymphoblastic leukemia (ALL) is a basis for treatment optimization. Currently, the most widely used methods for the detection of minute residual malignant cells in the bone marrow and/or peripheral blood, minimal residual disease (MRD), are PCR and flow cytometry (FCM). Immunophenotypic modulation (IM) is a well known factor that can hamper the accurate FCM analysis.

Aim: To report the IM detected by 8-color FCM during the BFM-type remission induction in 24 consecutive MRD-positive samples of children with B-cell precursor ALL and the possible implications for MRD detection.

Patients and methods: Between 2010 and 2012 we prospectively followed up the MRD on days 15 and 33 of induction treatment in bone marrow (BM) samples and on day 8 in peripheral blood (PB). The IM was assessed by comparative analyses of the changes in the mean fluorescence intensity of 7 highly relevant antigens expressed by the leukemic cells and normal B-lymphocytes.

Results: IM occurred, to different extents, in all analyzed day $15 \mathrm{BM}$ and in most day 33 BM samples. Statistically significant changes in the MFI-levels of four CDs expressed by the leukemic blasts were observed: downmodulation of CD10, CD19 and CD34 and upmodulation of CD20. No changes in the expression of CD38, CD58 and CD45 were noticed.

Conclusions: Measuring the MRD by standardized 8-color flow cytometry helps improve the monitoring of the disease, leading to better therapeutic results. However, the IM of the different antigens expressed by the leukemic blasts should be taken into consideration and cautiously analyzed.

\section{INTRODUCTION}

Recent studies demonstrating the prognostic significance of minimal residual disease (MRD) detection in childhood acute lymphoblastic leukemia (ALL) during remission induction have yielded a strong clinical implication for the management of these patients. ${ }^{1-5}$ Currently, the most widely used, highly sensitive $\left(1 \times 10^{-4}-1 \times 10^{-5}\right)$ and specific methods, are immunophenotyping by multi parameter flow cytometry (FCM) and real-time quantitative PCR (RQ-PCR). ${ }^{6-9}$ The time point-dependent concordance of FCM and RQ-PCR has also been shown. ${ }^{10,11}$ Briefly, FCM utilizes the aberrant phenotypic expression of leukemic cells to discriminate them from their normal counterparts. ${ }^{12-14}$ The stability of the leukemia-associated immunophenotype (LAIP) during therapy influences the FCM sensitivity and specificity. Such changes in the LAIP (also known as therapeutic immunophenotypic modulation, TIM) have continuously been described and include changes of the level of expression, acquisition or loss of lineage-associated antigens, or lineage switch. ${ }^{15}$ These could lead to false negative FCM results. ${ }^{16}$ Modern flow cytometers give the advantages of simultaneous staining with multiple immunophenotypic markers ( $>6$ colors) which could help prevent compromising the analysis. ${ }^{17-19}$ 


\section{AIM}

In this first Bulgarian childhood precursor B-cell ALL MRD study we report the immunophenotypic modulation detected by 8 -color FCM during the BFM-type remission induction in 24 consecutive children with B-cell precursor ALL and the possible implications for MRD detection.

\section{PATIENTS AND METHODS}

\section{PATIENTS}

From December 2010 to December 2012, a series of 43 children with ALL were consecutively diagnosed and treated in the pediatric oncohematology departments of Plovdiv and Varna University Hospitals, Bulgaria. Leukemia associated phenotypes (B- and TCP) were detected in 40 and a total of 31 patients were systematically followed up. Of these, 24 subjects (13 girls, 11 boys, median age $7 \mathrm{yrs}$, range $17 \mathrm{mos}-17 \mathrm{yrs}$ ), were included in this study according to the following criteria: 1 . B-cell precursor phenotype; 2. LAIP, suitable for MRD analysis; 3. Flow cytometric MRD-positivity (a cluster of $\geq 30$ cells with related characteristics) in the peripheral blood (PB) and/or in bone marrow (BM) follow-up samples. The study was approved by the institutional ethics committee and individual written informed consents were obtained by the patients' guardians. Flow cytometry was performed in the immunological research facility of the Plovdiv Medical University.

All these 24 patients received a BFM-type induction therapy. Later on the treatment continued according to the assigned risk group. Twenty-three patients were prednisone good responders (PGR) according to the protocol criteria (less than 1000 blasts/ $\mu 1 \mathrm{~PB}$ on day 8 , as assessed by morphological evaluation). The prednisone poor responding (PPR) subject (morphologically more than 1000 blasts $/ \mu 1 \mathrm{~PB}$ on day 8 ) was also the only Pro-B ALL case, the rest being classified as "common" or Pre-B ALL. Six patients were MRD negative $(<0.01 \%)$ on day 33. Diagnostic non-malignant BM samples $(n=8)$ and BM from pediatric T-ALL patients $(n=7)$ undergoing the same treatment were used for comparisons. Twenty patients had a normal karyotype, translocation $\mathrm{t}(9 ; 22)$ was found in two cases and translocation $\mathrm{t}(12 ; 21)$ was also found in two out of the 24 analyzed patients as assessed by the initial molecular and cytogenetic screening.

\section{FLOW CYTOMETRY}

Both PB and BM samples were collected at diagnosis. Follow-up samples for MRD studies were collected from PB at day 8 and from BM at days 15 and 33. Leukemia-associated immunophenotypes were assessed by 8 -color multiparametric FCM. The BCP-panel consisted of the following fluorochromeconjugated antibodies: SYTO41 Pacific Blue/ CD45 Pacific Orange/ CD58 FITC/ CD10 PE/ CD34 PerCP-Cy5.5/ CD38 PE-Cy7/ CD19 APC/ CD20 APC-Cy7. Antibodies to CD45 and SYTO41 were provided by the local representative of Molecular Probes, Invitrogen, and the rest - by the local representative of Becton Dickinson (BD, USA).

Stain-lyse procedure was used. Briefly, BM or PB sample was incubated with the antibodies for $15 \mathrm{~min}$ at room temperature. For red blood cell lysing, $2 \mathrm{ml}$ of 1:10 demineralized water-diluted commercially available solution (BD Lysing solution, 10x concentrate) was added for 10 minutes. Specimens were centrifuged at $400 \mathrm{G}, 4^{\circ} \mathrm{C}(1400$ $\mathrm{rpm})$ for $10 \mathrm{~min}$. Then the pellet was washed in phosphate-buffered saline (PBS), again centrifuged and finally the pellet was resuspended in 0.5 $\mathrm{ml}$ of PBS. The cell-permeant, live-cell nucleic acid fluorochrome SYTO 41 was added prior to measurement, in order to exclude residual nonnucleated erythroid cells, thrombocytes, or debris. All samples were processed within 24 to $48 \mathrm{~h}$ after collection. At diagnosis and on day 8 a total of 100000 SYTO41+ cells were collected. In order to achieve a sensitivity of at least $1 \times 10^{-4}$ on day 15 the cell input was increased to 300000 SYTO41+ events, and on day 33- one million SYTO41+ events were collected. Cell acquisition and the following analyses were performed using a BD FACS Canto II flow cytometer (BD, USA), in 4-2-2 configuration $(405,488$ and $635 \mathrm{~nm})$ with BD FACS Diva v. 6.1.3 software. Due to the low number of cases instrument setup was carried out at the beginning of each acquisition day (no less than once weekly) using the BD Cytometer Setup and Tracking (CST) Beads and the cytometer's CST module.

\section{Gating STRATEGy}

Combined immunological gate: CD19 expressionbased and by a physical parameter $\left(90^{\circ}\right.$ side scatter) was used for the initial B-lineage restriction (Fig. 1). Then leukemic cells were discriminated from the normal B lymphocytes on the basis of 

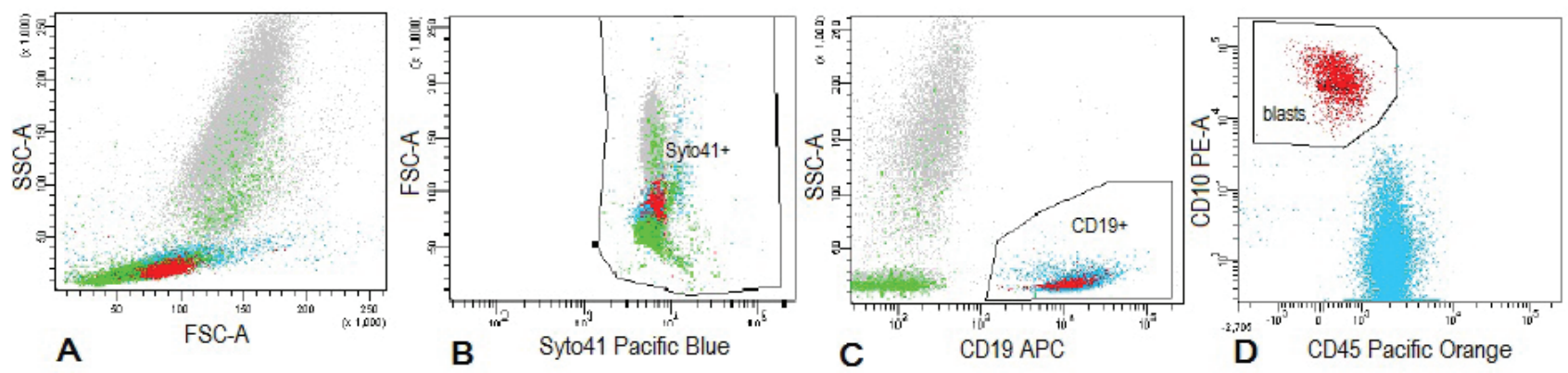

Figure 1. Gating strategy. Sequence of the analysis (A to D): A - general presentation of the populations in FSC/ SSC - dot plot. B - SSC/Syto41®- dot plot. Only Syto41®-positive events are acquired; C - in SSC /CD19-dot plot, the analysis is restricted to CD19+ events; D - determining the MRD in the field CD10/CD45; additional secondary dot plots are used to determine the expression of other CD-markers (not shown). All Syto41®-positive events are colored gray; CD19+ events are in blue; green represents the CD19-negative events; MRD-leukemic cells are stained in red.

leukemia-associated immunophenotypes (i.e. overexpression of antigens such as CD10, CD34, CD58, CD38 and/or underexpression of CD20 and CD45). Antigen expression was quantified using the mean fluorescence intensity (MFI) values, measured by the cytometer.

\section{STATISTICAL ANALYSis}

The Wilcoxon signed ranks test was used to compare the median MFI values at diagnosis and at follow-up time points. The results of the quantitative variables are indicated as an arithmetic mean or a median. Comparison of quantitative variables between two groups was performed by independent T-test or Mann-Whitney U test and for more than two groups - using One-Way ANOVA. The adopted significance level was $\mathrm{p}<0.05$. Box- and whisker plots and run charts are used for descriptive purposes.

\section{RESULTS}

\section{Modulation In LeUKemic CeLLS}

We examined the median MFI values of seven highly relevant antigens - CD10, CD20, CD34, CD38, CD58, CD19 and CD45, expressed by the leukemic blasts in the MRD positive samples. As an internal control we analyzed the changes of the forward scatter (FSC) and side scatter (SSC) properties of the leukemic cells. Moreover, we also checked the expression of CD19, CD20, CD45 and CD58, FSC and SSC of the residual normal CD19+ cells in each sample. Paired samples from diagnosis and early follow-up from 24 consecutive B-cell precursor ALL cases (PB: day 0 - day 8; BM: day 0 - day 15 , day 15 - day 33 and day 0 - day 33) were investigated. Immunophenotypic modulation occurred, to different extents, in all analyzed day 15 BM samples and in most day 33 BM samples compared to diagnosis. We observed statistically significant changes in the MFI levels of four CDs expressed by the leukemic blasts: CD10, CD20, CD34 and CD19 (Fig. 2). Downmodulation of CD10 was noticed in the interval day 0 - day 33, predominantly in the second half- after day 15 (Z: -3.007; $P=0.003$ ). Significant downmodulation was also seen for CD34 on day 15 (Z: -3.425; P $=0.001)$ and on day $33(\mathrm{Z}:-2.213 ; \mathrm{P}=0.027)$ in BM. By contrast, small but stable upmodulation was detected for CD20 both on day 15 (Z: 1.964; $\mathrm{P}=0.05)$ and on day $33(\mathrm{Z}: 1.891 ; \mathrm{P}=0.05)$. Curiously, CD19 showed significant upmodulation on day 15 (Z: -2.16; P < 0.001), but later on day 33 we noted a steep downmodulation ( $Z$ : -4.02 ; P $<0.0014)$. On the other hand, expression of CD58, CD45 and CD38 was not significantly changed at all time points. Analyses for the same antigens by comparing $\mathrm{PB}$ samples at diagnosis and at day 8 yielded very similar results: CD34 downmodulation (Z: -2.89; $\mathrm{P}=0.004), \mathrm{CD} 19$ (Z: -2.44; $\mathrm{P}=0.015$ ) and CD20 (Z: $-2.84 ; \mathrm{P}=0.005)$ upmodulation; no changes for CD38, CD45 and CD58. Of note, there was also no modulation detected for CD10 (Z: -0.23; $\mathrm{P}=0.82$ ). Scattergram (FSC vs. SSC) analyses of the leukemic cells confirmed that these blasts were always situated in the viable cells' regions. Furthermore, no significant changes in their FSC and SSC linear channel values, measured both at diagnosis and on follow-up, were seen. An example of IM as seen on the dot plots is given in Fig. 4.

Modulation in NORMal RESidual CELlS

There was a statistically significant reduction in the 

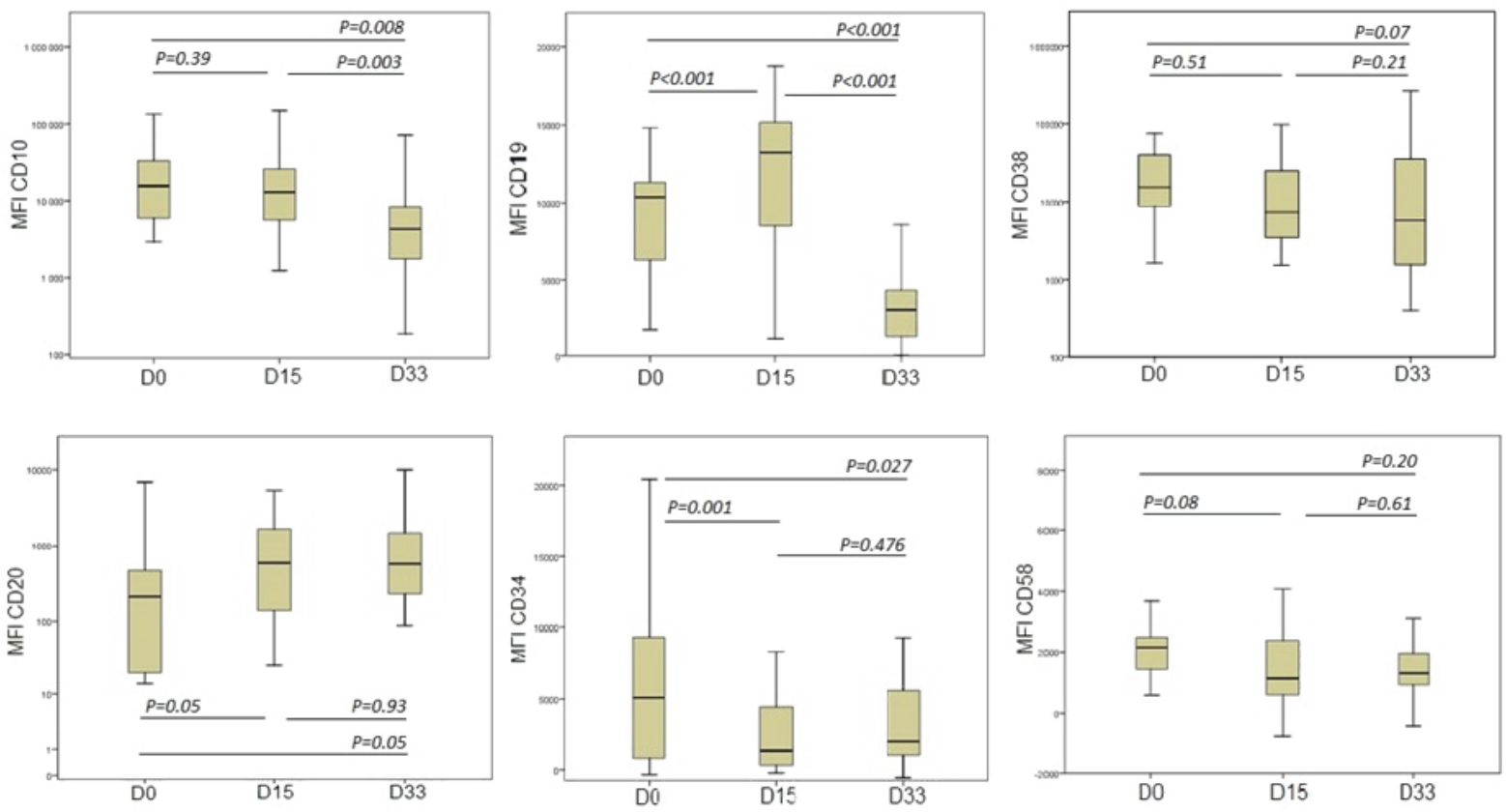

Figure 2. Modulation of leukemic cells. Changes in the MFI of CD10, CD19, CD20, CD38, CD34 and CD58 during induction therapy. D0, D15 and D33 mark the day of diagnosis, day 15 and day 33 of therapy. The levels of statistical significance are given in each box above the respective interval investigated.
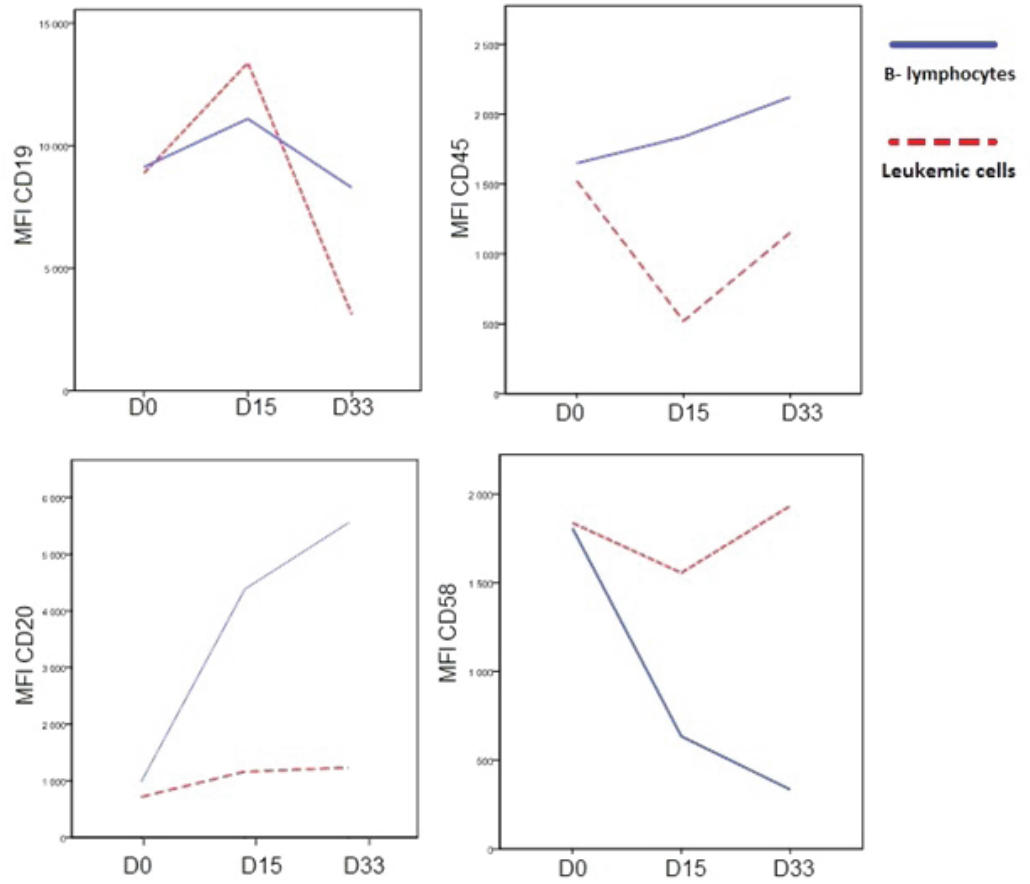

Figure 3. Modulation of B-lymphocytes. Changes in the MFI of CD19, CD20, CD45 and CD58, expressed by the leukemic cells (in red dashed line) compared to that of normal mature B-lymphocytes (in blue solid line).

proportion of leukemic cells among total CD19+ population (day 0 - day 33; Z:-3.82; $\mathrm{P}<0.001$ ), the greatest being during the first two weeks of induction treatment ( $\mathrm{Z}:-4.11 ; \mathrm{P}<0.001)$ : day $0: 86.49 \%$; day 15 : 19.55\%; day 33: $4.93 \%$. Therefore sufficient counts of normal CD19+, CD10 low/-, CD20++, CD38-, CD34-, CD45++ B-lymphocytes for analysis were present at any time point of the study. Accordingly, we examined whether only the leukemic population is subjected to IM, by analyzing the variations in the expression of CD19, CD20, CD58 and CD45 by the normal residual B-cells. As shown in Fig. 3 , the antigen expression patterns of normal mature $B$ cells frequently appeared to undergo modulation. 

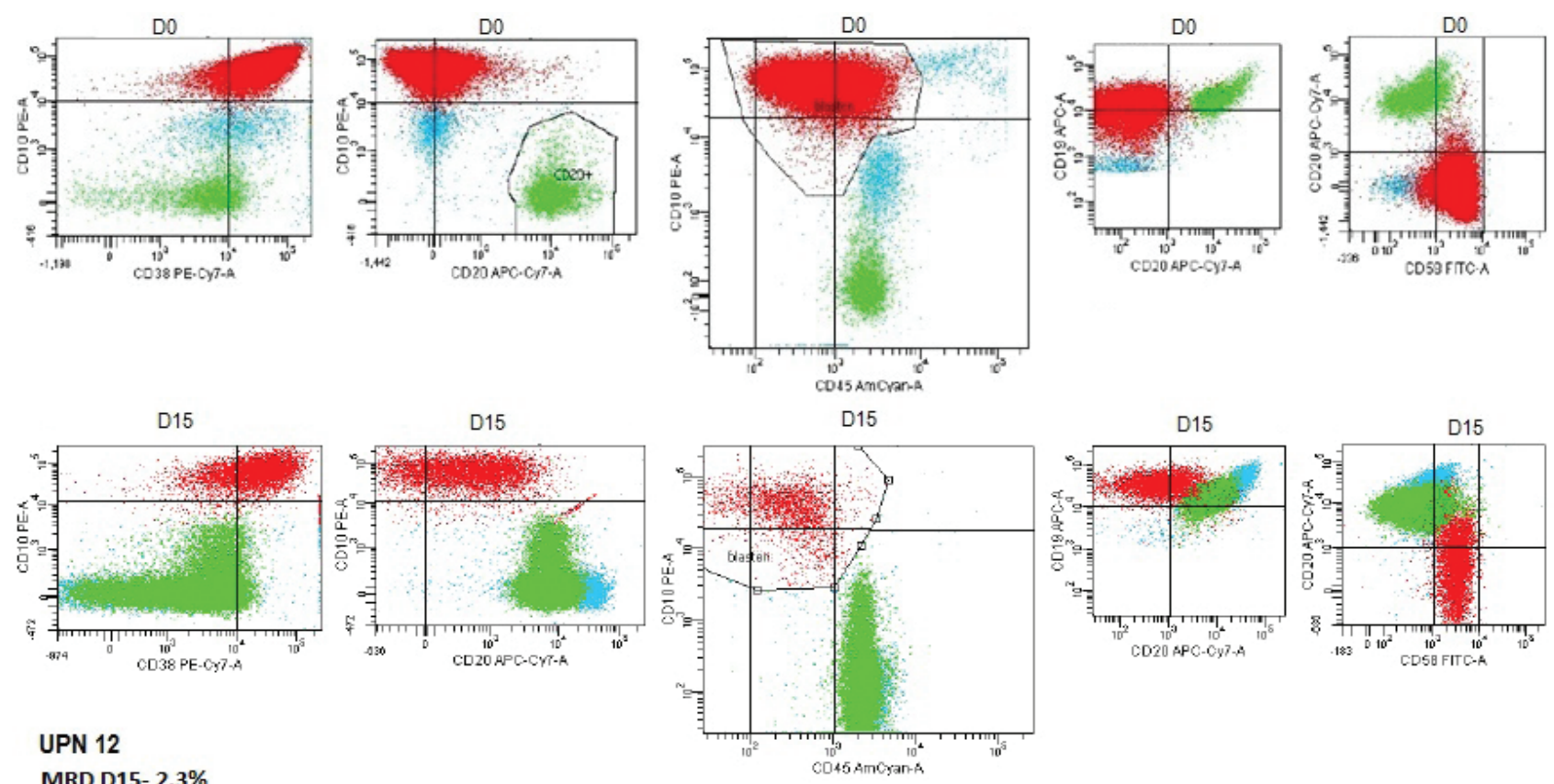

UPN 12

MRD D15- $2.3 \%$

Figure 4. Visual comparison of representative dot plots from the diagnosis (D0) in the upper row and follow-up (D15) in the lower row of a child with precursor B-cell ALL. All Syto41®-positive events are colored gray; CD19+ events are in blue; green represents the CD20+CD10- "mature" compartment; MRD-leukemic cells are stained in red. Shifts of the leukemic cells are clearly seen, aided by the superimposed referent lines.

Statistically significant downmodulation of CD19 was found between day 15 and day 33 (Z: -2.66; $\mathrm{P}=0.008$ ) (Fig. 3). In terms of CD20 and CD45, significant upmodulation was noted both on day 15 (CD20 Z: -3.59; P < 0.001 and CD45 Z: -3.23; P $=0.001)$ and on day $33(\mathrm{CD} 20 \mathrm{Z}:-3.81 ; \mathrm{P}<0.001$ and CD45 Z: $-2.98 ; \mathrm{P}=0.003)$. The expression of CD58 by the normal residual B-lymphocytes showed substantial downmodulation in both time points: day $15(\mathrm{Z}:-3.46 ; \mathrm{P}=0.001)$ and day $33(\mathrm{Z}$ : $-2.21 ; P=0.03)$. Similarly, day 8 PB results were compared to those from diagnosis and modulation of the same pattern was noted.

\section{DISCUSSION}

Immunophenotypic modulation of the leukemic cells during chemotherapy is a well-known phenomenon which could hamper the MRD analysis. This first Bulgarian pediatric ALL MRD prospective study reports changes in the median MFI-values of four of the analyzed CD-markers during the induction, although some data vary in a time-point aspect as compared to data published so far. ${ }^{20-22}$ Differences concern the downmodulation of CD10 that has been detected mostly after day 15 and persists in all day 33 MRD-positive samples. The upmodulation of CD19 is verified on day 15 , followed by a significant downmodulation on day 33. Changes in the modulation of CD34 and CD20 are similar to those already reported in other studies, as well as the stable expression of CD58 detected on day 15. Additionally, no statistically significant modulation was also found for CD38 and CD45. Taken together, knowing the usual pattern of the different CDs' MFI changes during the induction therapy is of crucial importance and could help facilitate the differentiation of the MRD-population in cases with concurrent modulation of one or several antigens.

In this study we have not investigated directly the possible mechanism unlocking the IM, although we favour the hypothesis that it could be druginduced, specifically by the corticosteroids, which are known regulators of gene transcription. In line with this, we observed IM as early as on day 8 in PB (after 7 days of prednisone and a single intrathecal injection of methotrexate). Moreover normal mature B cells in our study were also subjected to IM to some extent and these findings are in line with those of earlier studies. ${ }^{23}$

A possible demerit of the study is the difference in the expression of CD45, CD19 and CD58 on day 33, compared to those found in earlier studies. $^{22-24} \mathrm{We}$ assume that the relatively low number of MRD-positive patients at the end of the 
induction could have biased these specific results and warrant further research. On the other hand, variable CD binding, diverse antibody conjugates, distinct lysing procedure and the flow cytometer type with its compensation settings could also lead to such changes in measured MFI-values. High quality analyses require strict implementation of the internationally accepted standards for flow cytometric ALL MRD detection. ${ }^{25-29}$ That is why we applied uniform staining and lysing procedure, by using commercially available monoclonals and lysing solution in quantities recommended by the manufacturer. Stability of the flow cytometer was checked weekly using standard BD FACS CST kit and BD FACS 7-Color setup beads and showed no faults. Uniform gating strategy was accepted. In our case divergent results could probably be explained by the different cell clones used. Unfortunately, we could not prove it by simultaneous staining with another conjugates of the same CDs due to limited resources.

An advantage of our panel, similarly to Dworzak et al., 2002, is the acquisition based on the specific live-cell-permeant nucleated-cell dye Syto $41{ }^{\circledR}$ positivity, which together with the FSC and SSC parameters ensures that changes in the expression of antigens (hence TIM) are not a consequence of non-specific abstraction of fluorophores by debris. Additionally, we also looked for and visually ruled out MRD-subclone selection.

Chemotherapy leads to changes in the antigen expression of both the leukemic population $(\mathrm{CD} 10+/++$, CD20low/-, CD38++, CD34+/++, CD45low/-), and the remaining mature B-lymphocytes (CD10 low/-, CD20++, CD38-, CD34-, CD45++, CD19+). ${ }^{23,32}$ In the present study, we found a five-fold higher level of upmodulation of CD20, two-fold higher upmodulation of CD45 and significant downmodulation of $\mathrm{CD} 58$ expressed by the B-lymphocytes when compared to that of the leukemic cells. This favoured the visual differentiation of the MRDpopulation that remained outside the areas usually occupied by the "normal" cells in all dot plots. It has been shown that increasing the number of CD-antibodies $(\geq 6)$ in a single strategic, one-tube combination, could further increase the specificity and sensitivity of the analysis up to $1 \times 10^{-5}$ and reduce the risk of false negativity due to the IM or cell loss. ${ }^{2,25,31}$ Based on the variegated immunophenotypic modulation of malignant and normal B-lymphocytes during the early induction therapy and by using 8-color flow cytometry we were able to unambiguously distinguish the MRD-population in all samples relying on at least 4 different $C D$ markers with known pattern of modulation.

\section{CONCLUSIONS}

Our results confirm the presence of specific immunophenotypic changes occurring during the induction treatment of children with ALL. Dominating steroids in this phase could have triggered this phenomenon and researchers and routine laboratory workers should take it into account. The proposed standardized 8-color combination is suitable for multiparametric FCM detection of MRD in children with ALL, while minimizing the negative impact of TIM, and increasing the sensitivity of the analysis. Further identification of new leukemia markers which are easily detectable and are stably expressed in ALL cases could help discriminate reliably leukemic blasts from normal regenerating and mature cells, and therefore could improve MRD studies and extend the benefit to all patients.

\section{REFERENCES}

1. Borowitz MJ, Devidas M, Hunger SP, et al. Clinical significance of minimal residual disease in childhood acute lymphoblastic leukaemia and its relationship to other prognostic factors: A Children's Oncology Group study. Blood 2008;111:5477-85.

2. Campana D. Minimal residual disease monitoring in childhood acute lymphoblastic leukemia. Curr Opin Hematol 2012;19(4):313-8.

3. Bartram CR, Schrauder A, Köhler R, Schrappe M. Acute lymphoblastic leukemia in children. Treatment planning via minimal residual disease assessment. Dtsch Arztebl Int 2012;109(40):652-8.

4. Möricke A, Reiter A, Zimmermann M, et al. Riskadjusted therapy of acute lymphoblastic leukemia can decrease treatment burden and improve survival: treatment results of 2169 unselected pediatric and adolescent patients enrolled in the trial ALL-BFM 95. Blood 2008;111:4477-4489.

5. Dworzak MN, Pancer-Grumayer ER. Flow cytometric detection of minimal residual disease in acute lymphoblastic leukemia. Leukemia \& Lymphoma 2003;44(9):1445-1455.

6. Béné MC, Kaeda JS. How and why minimal residual disease studies are necessary in leukemia: a review from WP10 and WP12 of the European LeukaemiaNet. Haematologica 2009;94(8):1135-1150.

7. Coustan-Smith E, Ribeiro RC, Stow P, et al. A simplified flow cytometric assay identifies children with acute lymphoblastic leukaemia who have a superior clinical outcome. Blood 2006;108:97-102. 
8. Campana D, Yokota S, Coustan-Smith E, et al. The detection of residual acute lymphoblastic leukaemia cells with immunologic methods and polymerase chain reaction: a comparative study. Leukemia 1990;4:609-14.

9. Cazzaniga G, Biondi A. Molecular monitoring of childhood acute lymphoblastic leukaemia using antigen receptor gene rearrangements and quantitative polymerase chain reaction technology. Haematologica 2005;90:382-90.

10. Gaipa G, Cazzaniga G, Valsecchi MG, et al. Time point-dependent concordance of flow cytometry and real-time quantitative polymerase chain reaction for minimal residual disease detection in childhood acute lymphoblastic leukemia. Haematologica 2012;97(10):1586-1593.

11. Malec M, van der Velden VH, Björklund E, et al. Analysis of minimal residual disease in childhood acute lymphoblastic leukaemia: comparison between RQ-PCR analysis Ig/TcR gene rearrangements and multicolor flow cytometric immunophenotyping. Leukemia 2004;18:1630-6.

12. Campana D, Coustan-Smith E. Detection of minimal residual disease in acute leukaemia by flow cytometry. Cytometry 1999;38:139-52.

13. Dworzak MN, Stolz F, Fröschl G, et al. Detection of residual disease in pediatric B-cell precursor acute lymphoblastic leukaemia by comparative phenotype mapping: a study of five cases controlled by genetic methods. Exp Hematol 1999;27:673-81.

14. Fiser K, Sieger T, Schumich A, et al. Detection and monitoring of normal and leukemic cell populations with hierarchical clustering of flow cytometry data. Cytometry Part A 2012;81A:25-34.

15. Abshire TC, Buchanan GR, Jackson JF, et al. Morphologic, immunologic and cytogenetic studies in children with acute lymphoblastic leukaemia at diagnosis and relapse: a Pediatric Oncology Group study. Leukemia 1992;6:357-362.

16. Coustan-Smith E, Behm FG, Sanchez J, Boyett JM, Hancock ML, et al. Immunological detection of minimal residual disease in children with acute lymphoblastic leukaemia. Lancet 1998;351:550-4.

17. Wood B. 9-Color and 10-color flow cytometry in the clinical laboratory. Arch Pathol Lab Med 2006; 130:680-90.

18. Øbro NF, Ryder LP, Madsen HO, et al. Identification of residual leukemic cells by flow cytometry in childhood B-cell precursor acute lymphoblastic leukemia: verification of leukemic state by flow-sorting and molecular/cytogenetic methods. Haematologica 2012;97(1):137-141.

19. Ratei R, Basso G, Dworzak MN, et al. Monitoring treatment response of childhood precursor B-cell acute lymphoblastic leukemia in the AIEOP-BFMALL 2000 protocol with multiparameter flow cytometry: predictive impact of early blast reduction on the remission status after induction. Leukemia 2008;23(3):528-534.

20.Campana, D. Determination of minimal residual disease in leukemia patients. British Journal of Haematology 2003;121:823-838.

21. Gaipa G, et al. Prednisone induces immunophenotypic modulation of CD10 and CD34 in non-apoptotic B-cell precursor acute lymphoblastic leukemia cells. Cytometry B Clin Cytom 2008;74,150-155.

22. Dworzak MN, Gaipa G, Schumich A, et al. Modulation of antigen expression in B-cell precursor acute lymphoblastic leukemia during induction therapy is partly transient: Evidence for a drug-induced regulatory phenomenon. Results of the AIEOPBFM-ALL-FLOW-MRD-Study Group. Cytometry Part B 2010;78B:147-153.

23. Gaipa G, Basso G, Maglia O, et al. Drug-induced immunophenotypic modulation in childhood ALL: implications for minimal residual disease detection. Leukemia 2005;19:49-56.

24. Campana D, Coustan-Smith E. Advances in the immunological monitoring of childhood acute lymphoblastic leukemia. Best Practise and Research Clinical Hematology 2002;15(1):1-19.

25. Brüggemann M, Schrauder A, Raff T, et al. Standardized MRD quantification in European ALL trials: Proceedings of the Second International Symposium on MRD assessment in Kiel, Germany, 18-20 September 2008. Leukemia 2010;24:521-535.

26. Dworzak MN, Gaipa G, Ratei R, et al. Standardization of flow cytometric minimal residual disease evaluation in acute lymphoblastic leukaemia: multicentric assessment is feasible. Cytometry B Clin Cytom 2008;74(B):331-340.

27. Irving J, Jesson J, Virgo P, et al. Establishment and validation of a standard protocol for the detection of minimal residual disease in $\mathrm{B}$ lineage childhood acute lymphoblastic leukemia by flow cytometry in a multi-center setting. Haematologica 2009;94:870-874.

28. Kalina T, Flores-Montero J, van der Velden VHJ, et al. EuroFlow standardization of flow cytometer instrument settings and immunophenotyping protocols. Leukemia 2012;26:1986-2010.

29. van Dongen JJM, Lhermitte L, Boettcher S, et al. EuroFlow antibody panels for standardized ndimensional flow cytometric immunophenotyping of normal, reactive and malignant leukocytes. Leukemia 2012;26:1908-1975.

30. Dworzak MN, Fröschl G, Printz D, et al. Prognostic significance and modalities of flow cytometric mini- 
mal residual disease detection in childhood acute lymphoblastic leukemia. Blood 2002;99(6):1952-8.

31. Domingo E, Moreno C, Sánchez-Ibarrola A, Panizo C, Páramo JA, Merino J. Enhanced sensitivity of flow cytometry for routine assessment of minimal residual disease. Haematologica 2010;95:691-692.
32. Ratei R, Karawajew L, Lacombe F, et al. Normal lymphocytes from leukemic samples as an internal quality control for fluorescence intensity in immunophenotyping of acute leukemias. Cytometry Part B (Clinical Cytometry) 2005;70B:1-9.

\title{
Иммунофенотипическая модуляция бластных клеток при обнару- жении минимального остаточного заболевания детским острым лимфобластным лейкозом
}

\author{
Хасан А. Бурнусузов ${ }^{1}$, Мария И. Спасова ${ }^{1}$, Мариана А. Мурджева ${ }^{2}$ \\ Ангелина А. Стоянова', Иван Н. Мумджиев ${ }^{1}$, Валерия И. Калева', \\ Милена И. Белчева, Мирослава Н. Бошева ${ }^{1}$

\footnotetext{
${ }^{1}$ Отделение педиатрии и медицинской генетики, Факультет медицины, Медицинский университет, Пловдив

${ }^{2}$ Кафедра микробиологии и иммунологии, Факультет фармации, Медицинский университет, Пловдив

${ }^{3}$ Отделение педиатрии и медицинской генетики, Медицинский университет, Варна, Болгария
}

Раннее обнаружение лейкозных клеток во время индукционной терапии детского острого лимфобластного лейкоза (ALL) является основой оптимизации лечения. В настоящее время наиболее широко используемые методы обнаружения остаточных злокачественных клеток в костном мозге и/или периферической крови при минимальной остаточной болезни (МОБ) являются ПЦР и проточная цитометрия (FCM). Иммунофенотипическая модуляция (ИМ) является хорошо известным фактором, который может воспрепятствовать точному анализу при FCM.

Цель: Сообщить об ИМ, обнаруженной с помощью 8-цветной проточной цитометрии во время индукции ремиссии BFM-типа в течение 24 последовательных МОБ-положительных образцов, полученных от детей с В-клеточным острым лимфобластным лейкозом из клеток-предшественников и возможных последствий для обнаружения МОБ.

Материал и методы: За период 2010 - 2012 годов мы, в соответствии с нашими предположениями, проводили последовательное наблюдение МОБ на 15 и 33 день индукционной терапии в костном мозге и на 8 день - в периферической крови. ИМ оценивали с помощью сравнительного анализа изменений средней интенсивности флуоресценции 7 исключительно значимых антигенов, выраженных лейкозными клетками и нормальными В-лимфоцитами.

Результаты: ИМ обнаруживалась, в разной степени, во всех анализированных пробах костного мозга на 15 день и в большинстве случаев на 33 день. Наблюдались статистически значимые изменения уровней средней интенсивности флуоресценции четырех CD (определителей класификации), выраженных лейкозными бластами: понижение уровня модуляции CD10, CD19 и CD34 и повышение уровня модуляции CD20. Никаких изменений в выражении CD38, CD58 и CD45 замечено не было.

Заключение: Измерение МОБ с помощью стандартизированной 8-цветной проточной цитометрии помогает улучшить контроль заболевания, что приводит к улучшению результатов лечения. Тем не менее, ИМ различных антигенов, выраженных лейкозными бластами, должны приниматься во внимание и осторожно анализироваться.

Ключевые слова: МОБ, проточная цитометрия, иммунофенотипическая модуляция, детский острый лейкобластный лейкоз 